Irena Mamczak-Gadkowska (Uniwersytet im. Adama Mickiewicza w Poznaniu) dr hab., irena.gadkowska@gmail.com ORCID iD: 0000-0003-0011-9266

\title{
Archiwiści II Rzeczypospolitej w służbie państwa i społeczeństwa
}

Działalność archiwistów międzywojennych w służbie państwa i społeczeństwa jest znacząca i wielowątkowa. Mówiąc o roli archiwistów w okresie II RP, nie sposób pominąć faktu, że swoją działalność państwowotwórczą rozpoczęli oni już $w$ trakcie I wojny światowej, przygotowując m.in. projekt dekretu archiwalnego, zapobiegając wywożeniu archiwaliów za granicę i niszczeniu dokumentacji oraz aktywnie uczestnicząc w pracach Biura Prac Kongresowych w Paryżu.

W oparciu o wypracowane przez wybitnych historyków i archiwistów projekty Reskryptu, a następnie Dekretu o archiwach państwowych i opiece nad archiwaliami z 7 lutego 1919 r., stworzono w II RP nowoczesny, oparty na wzorach zachodnich, scentralizowany model funkcjonowania sieci archiwów. Zarządzał nią podległy ministrowi wyznań religijnych i oświecenia publicznego Wydział Archiwów Państwowych (WAP), który pozwolił pod jednym kierownictwem skoncentrować wysiłki służb archiwalnych realizujących liczne i bardzo ważne zadania, stojące przed tymi instytucjami. Już więc u progu niepodległości funkcjonowanie archiwów i służby archiwalnej regulowało nie tylko nowoczesne prawo archiwalne, ale także wiele przepisów wykonawczych (regulaminów archiwalnych), które normowały prawie wszystkie obszary działalności archiwów i służby archiwalnej ${ }^{1}$.

1 „Dziennik Praw Państwa Polskiego” 1919, nr 14, poz. 182; M. Motas, Pierwsze akty prawne o organizacji polskich archiwów państwowych i opiece nad archiwaliami z 31 lipca 1818 r. i z 7 lutego 1919 r., „Archeion” 1968, t. 50, s. 27-41; R. Piechota, B. Jagiełło, M. Motas, Pierwsze protokoły Rady Archiwalnej, cz. I, Protokoty Rady Archiwalnej, cz. II, Regulaminy archiwalne, „Teki Archiwalne” 1971, t. 13, s. 103-193. 
Dużą aktywnością wykazywali się także historycy, archiwiści i prawnicy, biorący udział w pracach Biura Prac Kongresowych Paryskiej Konferencji Pokojowej, obradującej w pierwszych miesiącach 1919 r., a zwłaszcza delegowani tam: kierownik WAP Józef Paczkowski oraz Marian Morelowski, którzy usilnie, chociaż ostatecznie bez skutku, zabiegali o wprowadzenie do postanowień traktatowych przepisów dotyczących rewindykacji Polsce dóbr kultury, w tym archiwaliów ${ }^{2}$. Obowiązek rewindykacji przez Wydział Archiwów Państwowych zbiorów archiwalnych, stanowiących własność państwa polskiego, zawarty został $\mathrm{w}$ dwóch pierwszych aktach prawnych dotyczących organizacji archiwów państwowych i opieki nad archiwaliami. Przepisy reskryptu, a następnie dekretu nakładały na Wydział obowiązek: zbierania informacji na temat archiwów i archiwaliów będących rezultatem działalności władz polskich lub obcych na terytorium Polski, opracowania planów rewindykacji oraz wykonania "uchwalonych zarządzeń", a więc wykonania postanowień umów rewindykacyjnych ${ }^{3}$.

Archiwiści międzywojenni bardzo aktywnie włączyli się w wielokierunkowei trudnestarania na rzecz rewindykacji, reewakuacji i restytucji archiwaliów przynależnych państwu polskiemu przede wszystkim z byłych państw zaborczych: Rosji, Niemiec i Austrii, ale także z Czechosłowacji i Rumunii. Pracom tym towarzyszyły rozważania teoretyczne archiwistów, przede wszystkim: Józefa Paczkowskiego ${ }^{4}$, Józefa Jana Siemieńskiego ${ }^{5}$ i Jadwigi Karwasińskiej ${ }^{6}$ na temat zasady przynależności terytorialnej. Wyjątkowe zaangażowanie najwybitniejszych archiwistów - na czele z naczelnymi dyrektorami archiwów państwowych - na rzecz rewindykacji archiwaliów na wszystkich etapach tego procesu, począwszy od pertraktacji z byłymi państwami zaborczymi i rejestracji zagrabionych archiwaliów, aż po odzyskanie i rekonstrukcję zasobów polskich archiwów państwowych, świadczy o wysokiej świadomości pojmowania przez nich roli i znaczenia archiwaliów dla zachowania dziedzictwa narodowego. Dzięki ich wyjątkowemu zaangażowaniu Polska odzyskała w okresie międzywojennym wiele cennych archiwaliów ${ }^{7}$.

2 I. Mamczak-Gadkowska, Józef Paczkowski i jego wkład w budowę polskiej służby archiwalnej, Warszawa-Łódź 1990, s. 107 i n.

${ }^{3}$ I. Mamczak-Gadkowska, Archiwa państwowe w II Rzeczypospolitej, Poznań 2006, s. 195221.

${ }^{4}$ J. Paczkowski, La remise des actes en connexion les changements de frontieres les Etatas, [w:] La Pologne au V-e Congres International des Sciences Historiques Bruxelles 1923, Warszawa 1924, s. 199-211.

${ }^{5}$ J. Siemieński, Respect des Fonds. Application international, [w:] VIII-e Congres International des Sciences Historiques, V. I - Communication presentees, Zurich 1938.

${ }^{6} \mathrm{~J}$. Karwasińska, La remise des archives dans les traites de l'Est Europeen, [w:] VIII-e Congres International des Sciences Historiques, V. I - Communication presentees, Zurich 1938.

${ }^{7}$ I. Mamczak-Gadkowska, Archiwa państwowe, s. 195-221. 
Ważnym elementem działalności archiwistów międzywojennych w służbie państwa były realizowane przez nich na zlecenie władz liczne kwerendy, które miały istotne znaczenie w płaszczyźnie stosunków międzynarodowych Polski z innymi państwami, zwłaszcza z byłymi zaborcami. Szczególne znaczenie dla odrodzonej Rzeczpospolitej miała kwerenda wykonana przez archiwistów poznańskich w latach 1920-1924 dla Delegacji Polskiej działającej w Komisji Odszkodowawczej w Paryżu. Przedmiotem tej kwerendy było ustalenie właścicieli majątków niemieckich, które po I wojnie z mocy traktatu wersalskiego znalazły się na terytorium przypadającym Polsce. W wyniku gruntownych i czasochłonnych poszukiwań (uzasadnienie obejmowało siedemset stron maszynopisu) ustalono, że 45 proc. przejętych po I wojnie przez Polskę majątków niemieckich, czyli ok. 355841 ha ziemi i lasów, stanowiły dawne królewszczyzny i majątki królewskie, które w następstwie rozbiorów stały się własnością rządu pruskiego ${ }^{8}$. W efekcie zwolniło to stronę polską od konieczności zapłacenia Niemcom ogromnego odszkodowania. Wielkie zasługi państwu polskiemu oddali także archiwiści na czele z kierownictwem Wydziału Archiwów Państwowych w sprawie uregulowania statusu AP w Gdańsku, które było w okresie międzywojennym przedmiotem polsko-gdańsko-niemieckiego sporu ${ }^{9}$.

Za równie ważne uznano w okresie międzywojennym nowe zadania archiwów i archiwistów w zakresie zabezpieczania i gromadzenia narastającego zasobu archiwalnego, czyniąc starania o jego zabezpieczenie $w$ archiwach, a także ściśle współpracując $\mathrm{z}$ urzędami i instytucjami państwowymi w zakresie tworzenia nowoczesnych przepisów kancelaryjnych i archiwalnych ${ }^{10}$. Zaangażowanie archiwistów $\mathrm{w}$ reformę biurowości oraz podjęcie przez służbę archiwalną szkolenia pracowników kancelarii i archiwów zakładowych wynikało ze świadomości niskiego poziomu kancelarii i registratur urzędów oraz instytucji państwowych, co w konsekwencji miało duży wpływ na jakość narastającego zasobu archiwalnego. Archiwiści - na miarę swoich możliwości i głównie na prośbę zainteresowanych instytucji - włożyli wiele wysiłku w działania na rzecz opieki nad archiwami niepaństwowymi: kościelnymi,

${ }^{8}$ AP Poznań, Archiwum Państwowe w Poznaniu, sygn. 6, s. 57-72; Kronika, red. W. Łopaciński, Archiwum Państwowe w Poznaniu w latach 1920-1926, "Archeion” 1928, t. 4, s. 159-160; K. Kaczmarczyk, Archiwum Państwowe w Poznaniu w latach 1919-1926, tamże, s. 145-146; I. Radtke, Dzieje Archiwum Państwowego w Poznaniu (1869-1999), „Poznański Rocznik Archiwalno-Historyczny” 1999/2000, r. VI/VII, s. 31-32.

${ }^{9} \mathrm{Na}$ ten temat szeroko: C. Biernat, Spór archiwalny polsko-gdańsko-niemiecki w okresie międzywojennym 1919-1939, Warszawa 1969; tegoż, Zatarg gdańsko-niemiecki w latach 1919-1930 o profil Archiwum Gdańskiego, „Archeion” 1968, t. 48, s. 85-97; M. Dragan, Polsko-gdańsko-niemiecki spór archiwalny w okresie międzywojennym (1919-1939), „Archeion” 1963, t. 39, s. 165-203; I. Mamczak-Gadkowska, Józef Paczkowski, s. 127-144.

${ }^{10}$ I. Mamczak-Gadkowska, Archiwa państwowe, s. 221-246. 
samorządowymi, instytucji naukowych, prywatnych i gospodarczych, których łączna liczba w 1938 r. wynosiła 282 (w tym: 11 archiwów samorządowych, 45 archiwów miast, 94 archiwa duchowne, 114 archiwów prywatnych oraz 18 archiwów uniwersyteckich, fundacyjnych i społecznych) ${ }^{11}$. Opieka ta przybierała różnorodne formy, począwszy od gromadzenia informacji na temat ich zasobów i bezpośredniego udziału przy porządkowaniu akt, przez prace naukowe dotyczące metodyki opracowania poszczególnych typów akt, aż po przejmowanie cenniejszych archiwaliów do archiwów państwowych $\mathrm{w}$ formie depozytów.

Urzędnicy Wydziału aktywnie uczestniczyli w reformie polskiej biurowości i przygotowaniu przepisów kancelaryjnych z lat 30. XX w. Przez cały okres międzywojenny służyli radami i fachową pomocą urzędom administracji państwowej wszystkich szczebli $\mathrm{w}$ zakresie opracowania instrukcji kancelaryjnych, organizacji registratur i porządkowania akt ${ }^{12}$. Przedmiotem szczególnej troski Wydziału w zakresie opieki nad aktami przechowywanymi w składnicach akt było przestrzeganie przez urzędy przepisów w zakresie brakowania dokumentów. W tym celu Wydział przeprowadzał kontrole urzędów zgłaszających zamiar brakowania akt oraz liczne wizytacje składnic akt ${ }^{13}$. Istniała ścisła współpraca archiwów państwowych $\mathrm{z}$ archiwami samorządowymi w Łodzi, Pabianicach, Płocku, Warszawie, Wilnie i Toruniu ${ }^{14}$. $\mathrm{Z}$ ramienia Wydziału pieczę nad właściwym funkcjonowaniem archiwów miejskich sprawowali głównie: Wincenty Łopaciński, Kazimierz Konarski, Kazimierz Kaczmarczyk oraz Aleksy Bachulski. Warto podkreślić, że miasta często same zwracały się o pomoc przy organizowaniu archiwów.

Archiwiści międzywojenni udzielali również pomocy i wsparcia archiwom kościelnym. Konieczność powołania w diecezjach komisji ochrony archiwaliów wynikała z postanowień art. XIV konkordatu polskiego zawartego z Watykanem w roku 1925. Z komisjami archiwalnymi ściśle współpracowali archiwiści Aleksy Bachulski oraz Wincenty Łopaciński, którzy udzielali wskazówek i instrukcji w zakresie gromadzenia i opracowywania archiwaliów kościelnych. Wydział przesyłał swoje regulaminy także kapitułom katedralnym we Włocławku, Poznaniu, Łodzi i Krakowie, organizującym własne archiwa ${ }^{15}$. Opieka merytoryczna Wydziału Archiwów Państwowych obej-

11 „Rocznik Polityczno-Gospodarczy” 1938, s. 516-524.

${ }^{12}$ H. Robótka, Archiwa państwowe i reforma biurowości w Polsce międzywojennej, "Archeion" 1994, t. 93, s. 83-87; tejże, Kancelaria urzędów administracji państwowej II Rzeczypospolitej. (Procesy aktotwórcze), Torun 1993.

${ }^{13}$ Sprawozdanie z dziatalności WAP w roku 1937, „Archeion” 1938-1939, t. 16, s. 139-146.

14 Archiwum Akt Dawnych m. Łodzi w r. 1926, „Archeion” 1927, t. 2, s. 178-182; Archiwum Akt Dawnych miasta Pabianic, tamże, s. 182-183.

${ }_{15}$ Sprawozdanie z działalności Wydziału Archiwów Państwowych w 1929 roku, „Archeion” 1930, t. 6-7, s. 2; S. Librowski, Stan i potrzeby archiwów kościelnych oraz program pracy na najbliższy okres, 
mowała również archiwa innych wyznań. W lipcu 1935 r. na prośbę metropolity Kościoła prawosławnego w Polsce o udzielenie pomocy w zorganizowaniu Centralnego Archiwum Metropolii Kościoła Prawosławnego, Wydział delegował do realizacji tego zadania Łopacińskiego, kierownika Archiwum Oświecenia Publicznego.

W roku 1928 Wydział Archiwów Państwowych przeprowadził ankietę $\mathrm{w}$ sprawie pozostałych $\mathrm{w}$ kraju akt po zaborcach i okupantach, związaną z pracami przygotowawczymi dotyczącymi organizacji archiwów wojewódzkich i powiatowych. W roku 1935, podczas VI Zjazdu Historyków Polskich w Wilnie głos zabrał w tej sprawie dyrektor Archiwum Państwowego w Lublinie Eugeniusz Barwiński, który opowiedział się m.in. za rozszerzeniem zakresu działania Wydziału Archiwów Państwowych na archiwa miejskie i gminne ${ }^{16}$.

Niezależnie od wymienionych wyżej działań, zarówno przez swoich delegatów, jak i za pośrednictwem konserwatorów lub urzędów wojewódzkich, archiwiści zbierali wiadomości o archiwaliach będących w rękach prywatnych. Ratowanie tych dokumentów od zniszczenia polegało na udzielaniu fachowych rad w sprawie ich konserwacji lub też na staraniach o przekazanie ich do właściwego archiwum państwowego. Ścisłe współdziałanie Wydziału z Departamentem Sztuki w sprawach dotyczących opieki i ratowania archiwaliów przez konserwatorów, a również z Departamentem Wyznań Religijnych w sprawie archiwów Kościołów innych wyznań, np. prawosławnego i unijnego, oraz z resortem administracji i urzędami wojewódzkimi, pozwoliło uchronić od zniszczenia wiele cennych i unikalnych dokumentów. Delegaci Wydziału odwiedzili w latach międzywojennych wiele miast i wsi, zwłaszcza na terenie byłego zaboru austriackiego, gdzie ilość cennych materiałów archiwalnych $w$ rękach prywatnych była największa ${ }^{17}$. Archiwiści II RP uczestniczyli również $w$ pracach nad opracowywaniem archiwów prywatnych, w tym zbiorów znanych rodzin i wielkich rodów szlacheckich. W kontekście owym należy przypomnieć uporządkowanie i zinwentaryzowanie Archiwum Potockich w Jabłonnie (Wincenty Łopaciński, Adam Moraczewski), Chodkiewiczów w Młynowie (archiwiści krakowscy) oraz wizytację archiwum Hochbergów w Pszczynie (Kazimierz Kaczmarczyk) ${ }^{18}$.

\footnotetext{
„Archiwa, Biblioteki i Muzea Kościelne” 1959, t. 1, z. 1, s. 21-23, 26-31; tegoż, Dotychczasowe osiagnięcia w dziedzinie reformy organizacji archiwów kościelnych w Polsce, „Archiwa, Biblioteki i Muzea Kościelne" 1961, t. 3, z. 1-2, s. 11-13.

${ }^{16}$ E. Barwiński, O archiwa miejskie i gminne (koreferat), [w:] Pamiętnik VI Powszechnego Zjazdu Historyków Polskich, Lwów 1935, t. I. s. 432-438. Wypowiedź Barwińskiego była odpowiedzią na referat J. Adamusa, O archiwa miejskie i gminne, tamże, s. 425-432.

17 Sprawozdanie z działalności WAP w roku 1929, "Archeion” 1930, t. 6-7, s. 2-3.

18 Sprawozdanie z dziatalności WAP w roku 1935, "Archeion” 1936, t. 14, s. 93; Sprawozdanie a działalności WAP w roku 1937, „Archeion” 1938-1939, t. 16, s. 148-149.
} 
Urzędnicy Wydziału Archiwów Państwowych oraz archiwiści w całej Polsce współpracowali także w przygotowaniu i realizacji rozporządzeń Prezydenta Rzeczypospolitej o pieczęciach i godłach państwowych z 1927 r., o godłach i barwach państwowych oraz o oznakach, chorągwiach i pieczęciach w brzmieniu z 24 listopada 1930 r. (następstwem tego rozporządzenia był okólnik Ministerstwa Spraw Wewnętrznych o herbach związków samorządowych z 1935 r.) ${ }^{19}$. Rola Wydziału Archiwów polegała głównie na opiniowaniu wniosków o zatwierdzenie lub nadanie herbów wojewódzkich, miejskich oraz znaków władz i urzędów państwowych i samorządowych. Opiekę nad stroną artystyczną pieczęci i herbów sprawował Departament Sztuki Ministerstwa WRiOP ${ }^{20}$. Wykonanie tego zadania wymagało zaangażowania znacznej liczby archiwistów we wszystkich archiwach, zwłaszcza ze względu na konieczność przygotowania materiału archiwalnego oraz konsultacji z najwybitniejszym polskim znawcą heraldyki prof. Władysławem Semkowiczem, prezesem Polskiego Towarzystwa Heraldycznego, oraz z wojewodami i starostami. Rada Archiwalna na swym szóstym posiedzeniu w grudniu 1928 r. powołała specjalną komisję do spraw herbów wojewódzkich w składzie: Leon Białkowski. Wacław Graniczny, Kazimierz Kaczmarczyk, Helena Polaczkówna, Władysław Semkowicz, Józef Siemieński, Wacław Studnicki, Jarosław Wojciechowski i Antoni Rybarski ${ }^{21}$. Komisja podjęła decyzję o zachowaniu starych herbów województw historycznych, dla województw nowych natomiast postanowiono tworzyć herby składające się z elementów historycznych, charakterystycznych dla terytorium, z którego województwo powstało ${ }^{22}$.

W styczniu 1930 r. Departament Sztuki zwrócił się do Wydziału Archiwów Państwowych o ustalenie wszystkich cech heraldycznych herbu państwa. Wydział powołał specjalną komisję do rozstrzygnięcia tej sprawy pod kierunkiem prof. Semkowicza. W jej skład wchodzili: Leon Białkowski, Adam Chmiel, Wacław Graniczny, Oskar Halecki, Wincenty Łopaciński, Helena Polaczkówna, Józef Siemieński, Józef Stojanowski. Jarosław Wojciechowski i Zygmunt Wdowiszewski. Komisja wydała negatywną opinię o przygotowanym wówczas projekcie herbu państwa, ustaliła szczegółowe wymagania heraldyczne oraz podjęła decyzję o rozpisaniu ograniczonego konkursu na

19 „Dziennik Ustaw” 1927, nr 115, poz. 980 (Rozporządzenie Prezydenta Rzeczypospolitej o pieczęciach i godłach państwowych); „Dziennik Ustaw” 1930, nr 80, poz. 629 (Rozporządzenie Prezydenta Rzeczypospolitej o godłach i barwach państwowych oraz o oznakach, chorągwiach i pieczęciach w brzmieniu z dn. 24. XI. 1930 r.).

${ }^{20}$ Dziat Urzędowy. Protokót posiedzeń VI-ej sesji Rady Archiwalnej w dn. 19 i 20 grudnia 1928 r., „Archeion" 1929, t. 5, s. 19-20.

${ }^{21}$ Tamże, s. 25.

${ }^{22}$ Dziat urzędowy. Protokót posiedzeń VII sesji Rady Archiwalnej w dn. 28 i 29 marca 1930 r., "Archeion" 1930, t. 8, s. 25-26. 
nowy projekt $\mathrm{t}^{23}$. Prowadzone $\mathrm{w}$ archiwach $\mathrm{w}$ szerokim zakresie badania heraldyczne były bardzo czasochłonne i długotrwałe. Większość przygotowanych w latach 1933-1934 wizerunków herbów miejskich przesłanych do zatwierdzenia przez Wydział była wadliwa pod względem heraldycznym oraz artystycznym. Powolne tempo prac związanych z opiniowaniem i zatwierdzaniem herbów miejskich spowodowane było, według Wydziału, głównie słabym stopniem opracowania polskiej heraldyki miejskiej i nieudolnym wykonywaniem wizerunków herbowych przez zarządy miejskie, co w efekcie powodowało konieczność sporządzania ich na nowo pod nadzorem WAP i przedłużało prace ${ }^{24}$. Pomimo niezbyt zadowalającego tempa tych prac Wydział Archiwów Państwowych wspólnie z MSW w końcu lat 30. zatwierdzili herby ponad osiemdziesięciu miast ${ }^{25}$.

Począwszy od 1929 r., Wydział Archiwów Państwowych wraz z archiwami państwowymi współdziałał także z Ministerstwem Spraw Wewnętrznych w „Komisji dla opracowania wniosków w sprawie ustalenia urzędowej nomenklatury miejscowości w Polsce" ${ }^{26}$. Państwowa służba archiwalna ściśle współpracowała $\mathrm{w}$ tej sprawie z komisjami przy urzędach wojewódzkich, które przygotowywały materiały odnośnie do ustalenia urzędowych nazw miejscowości w Polsce ${ }^{27}$.

Ważną rolę w zwiększeniu roli państwowej służby archiwalnej w zakresie kształtowania narastającego zasobu archiwalnego odegrały organizowane przez państwową służbę archiwalną kursy dla pracowników kancelarii i składnic akt urzędów centralnych, organizowane począwszy od 1930 r.,

${ }^{23}$ Tamże, s. 26.

${ }^{24}$ Sprawozdanie z działalności WAP w roku 1937, „Archeion” 1938-1939, t. 16, s. 147-148.

${ }^{25}$ W roku 1936 MSW wspólnie z WAP uzgodnili herby następujących miast: 1. Aleksandrow Łódzki, 2. Będzin, 3. Bielsk Śląski, 4. Bieruń Stary, 5. Brodnica, 6. Busko Zdrój, 7. Bydgoszcz, 8. Czeladź, 9. Czortków, 10. Gniezno, 11. Grabów Wlkp, 12. Halicz, 13. Janowiec Wlkp, 14. Kamionka Strumiłowa, 15. Krzywin, 16. Lublin, 17. Lubliniec, 18. Lwów, 19. Łęczyca, 20. Mysłowice, 21. Nieszawa, 23. Nieśwież, 23. Olesko, 24. Ostrzeszów, 25. Poznań, 26. Pszczyna, 27. Radzymin, 28. Rawicz, 29. Rydzyna, 30. Sędziszów, 31. Sienianowice Śląskie, 32. Skawina, 33. Szczekociny, 34. Śmigiel, 35. Środa, 36. Torun, 37. Tuchów, 38. Wilamowice, 39. Włodzimierz, 40. Wodzisław Śląski, 41. Wolsztyn, 42. Załoźce, 43. Zbąszyn, 44. Zgierz, 45. Złoczów, 46. Żory. W roku 1937 uzgodniono herby kolejnych miast: 1. Chełmża, 2. Chojnice, 3. Dubno, 4. Grudziądz, 5. Inowrocław, 6. Jordanów, 7. Katowice, 8. Kłobucko, 9. Konstantynów Łódzki, 10. Kórnik, 11. Krotoszyn, 12. Lubaczów, 13. Łańcut, 14. Myślenice, 15. Pelplin, 16. Pińsk, 17. Siedlce, 18. Stanisławów, 19. Tarnów, 20. Warszawa, 21. Wieruszów, 22. Żnin. Zob.: Sprawozdanie z dziatalności WAP w roku 1936, "Archeion” 1937-1938, t. 15, s. 149; Sprawozdanie z działalności WAP w roku 1937, „Archeion" 1938-1939, t. 16, s. 148.

${ }^{26}$ MSW, Okólnik nr 138, 6 VII 1929.

${ }^{27}$ Lietuvos Centrinis Valstybés Archyvas, Vilnius (dalej cyt. LCVA Wilno), Archiwum Państwowe w Wilnie. Ministerstwo Wyznań Religijnych i Oświecenia Publicznego. Rzeczpospolita Polska, 1920-1939 (dalej cyt. AP w Wilnie 1920-1939), zespół nr 286, sygn, 8, s. 165170 i $270-271$. 
przemiennie z kursami dla studentów i absolwentów uniwersytetu, które zapoczątkowane zostały w 1925 r. Kandydatów na kursy pozyskiwano, rozsyłając zaproszenia do ministerstw i instytucji centralnych z prośbą o kierowanie na szkolenie archiwalne urzędników odpowiedzialnych za obieg i przechowywanie dokumentów. Pięć kursów urzędniczych, które były znacznie liczniejsze niż kursy akademickie, ukończyło w latach 1930-1937 około dwustu urzędników administracji centralnej ${ }^{28}$. Nową formą kształcenia kadr archiwalnych na potrzeby archiwów państwowych była instytucja stypendystów-praktykantów, w prowadzona w połowie lat 30. XX w. w czterech ośrodkach akademickich i archiwalnych: w Warszawie, Poznaniu, Lwowie i Wilnie ${ }^{29}$.

Jedną $\mathrm{z}$ form udostępniania materiałów archiwalnych przez archiwa były i pozostają kwerendy archiwalne. $W$ tym kontekście należy podkreślić, że w pierwszych latach po wojnie praca wewnętrzna archiwów była determinowana potrzebami rewindykacji. Znakomitą większość kwerend stanowiły więc - niezależnie od wymienionych wyżej kwerend odszkodowawczych kwerendy realizowane dla uzasadnienia polskich żądań rewindykacyjnych. Były one prowadzone $w$ archiwach centralnych w Warszawie, głównie w Archiwum Głównym Akt Dawnych ${ }^{30}$, oraz w niektórych archiwach terenowych. Kolejnym etapem tych działań było przejmowanie przez archiwa państwowe akt rewindykowanych i reewakuowanch oraz gromadzenie $\mathrm{w}$ archiwach znacznej ilości zarchiwizowanych akt pozaborczych i pookupacyjnych. Do najważniejszych kwerend urzędowych, wykonanych przez archiwum w omawianym czasie, należały przeprowadzone dla celów delegacji rewindykacyjnej kwerendy odszkodowawcze w sprawie dóbr proaustriackich, mające na celu wykazanie dóbr kupionych i odziedziczonych przez Austrię od Rzeczy pospolitej (te ostatnie nie podlegały odszkodowaniu). Dzięki doskonałym ekspertyzom prawniczym $i$ archiwalnym przygotowanym przez dyrektora AGAD Józefa Siemieńskiego, a dotyczącym zarówno dóbr poaustriackich, jak i popruskich, państwo polskie uniknęło wielomilionowych odszkodowań na rzecz byłych państw zaborczych ${ }^{31}$.

Sporo czasu zajmowały także kwerendy dla osób prywatnych, urzędów państwowych, zwłaszcza Ministerstwa Spraw Zagranicznych, Ministerstwa Rolnictwa, Prokuratorii Generalnej, a także urzędów wojewódzkich, magistratów i instytucji. Największym ciężarem dla archiwów były kwerendy seryjne, przybierające bardzo rozległe rozmiary. $W$ okresie międzywojennym archiwum przeprowadziło trzy kwerendy o szerokim zakresie poszukiwań

${ }^{28}$ Dane orientacyjne na podstawie sprawozdań WAP zamieszczanych w Archeionie, t. 11, 1933, s. 84-85; tamże, t. 13, 1935, s. 164-165; tamże, t. 14, 1937-1938, s. 97; tamże, t. 16. 1938-1939, s. 151-152 oraz w artykule K. Konarskiego, Dziesięciolecie kursów..., s. 184.

${ }^{29}$ I. Mamczak-Gadkowska, Archiwa państwowe..., s. 159-162.

${ }^{30}$ Kronika. Archiwum Główne w Warszawie. Lata 1915-1926, Archeion, t. 4, 1928, s. 141.

${ }^{31}$ Tamże, s. 139-140. 
i kilka mniejszych. Do najważniejszych należały kwerendy naukowe związane z rocznicami powstań narodowych. Szczególne znaczenie społeczne miała kwerenda powstańcza, spowodowana dekretem o zasiłkach wypłacanych rodzinom powstańców z 1863 r., oraz kwerenda uprawniająca do zapomogi za udział w rewolucji 1905 r., a także kwerenda dotycząca akt gruntowych Wołynia, które strona polska otrzymała w wyniku rewindykacji. Najbardziej masowy charakter miała natomiast kwerenda przeprowadzona w Archiwum Akt Dawnych, związana z udziałem ludności w rewolucji $1905 \mathrm{r}$.

W Archiwum Skarbowym załatwiano rocznie średnio około półtora tysiąca kwerend i sporządzano po kilka tysięcy odpisów ${ }^{32}$. Według Stefana Kieniewicza, praca ta pochłaniała cały wysiłek personelu z oczywistą szkodą dla inwentaryzacji i opracowania zasobu. Do połowy lat 30., czyli w okresie kierownictwa Granicznego, inwentaryzowano przede wszystkim te części zespołów, w których przeprowadzano kwerendy i tylko w granicach niezbędnych do odszukania potrzebnych akt ${ }^{33}$. Znaczna część zasobu Archiwum Skarbowego miała istotne znaczenie dla ustalenia praw własności, wyjaśnienia spraw majątkowych, podatkowych oraz emerytalnych i dlatego była przedmiotem licznych kwerend urzędowych i prywatnych. Prowadzono kwerendy m.in. w zespołach Akt Wydziału Ziemskiego, Komisji i Komisarzy Włościańskich oraz Banku Włościańskiego, zawierających tytuły własności setek tysięcy drobnych rolników, a poza tym w zespołach Akt Prokuratorii i Zarządu Dóbr, zawierających dokumentację dotyczącą nieruchomości państwowych i sporów majątkowych państwa z osobami prywatnymi.

Kwerendy urzędowe i prywatne nie ominęły także najmniejszego z archiwów warszawskich - Archiwum Oświecenia Publicznego. Tylko w latach 1918-1926 przeprowadzono w nim 3300 kwerend, związanych głównie z: weryfikacją kwalifikacji nauczycielskich, zbiorami rękopisów Biblioteki Uniwersytetu Warszawskiego oraz materiałami dotyczącymi funduszy stypendialnych wywiezionych do Rosji ${ }^{34}$. Zarówno ze względu na charakter, jak i wielkość zasobu, archiwum to nie przeżywało wielkich fal poszukiwań związanych z obchodami rocznic powstań narodowych. Liczne kwerendy były również realizowane w Archiwum Wojskowym. Przedmiotem tych prac były głównie sprawy personalne oraz tzw. likwidacyjne, związane $\mathrm{z}$ roszczeniami rządowymi i prywatnymi wobec rządu niemieckiego z ty-

32 Sprawozdanie z działalności archiwów państwowych. Rok 1930, red.W. Łopaciński, „Archeion” 1930, t. 6-7, s. 48; Sprawozdanie... Rok. 1931, red. W. Łopaciński, „Archeion” 1931, t. 9, s. 72; Sprawozdanie... Rok 1932, oprac. W. Łopaciński, „Archeion” 1933, t. 11, s. 133.

33 S. Kieniewicz, Archiwum Skarbowe w Warszawie, [w:] Straty bibliotek i archiwów warszawskich w zakresie rękopiśmiennych źródeł historycznych, t. 2, Archiwa porozbiorowe i najnowsze, Warszawa 1956, s. 21.

${ }^{34}$ Kronika. Archiwum Oświecenia Publicznego w Warszawie w latach 1915-1926, „Archeion” 1927, t. 2, s. 172-173. 
tułu strat poniesionych wskutek działań władz okupacyjnych w czasie I wojnie światowej (rekwizycje, konfiskaty). Z zasobów Archiwum Wojskowego (następnie AAN) korzystały przede wszystkim dwa urzędy: Główny Urząd Likwidacyjny w Warszawie oraz Prokuratoria Generalna Rzeczypospolitej Polskiej3.

Bardzo zróżnicowane były kwerendy przeprowadzane przez archiwistów w archiwach państwowych w terenie. I tak Archiwum Państwowe w Grodnie od pierwszych lat po wojnie do początku lat 30. wykonywało średnio od kilkudziesięciu do kilkuset kwerend rocznie. Przeważały prace dla władz urzędów państwowych, rosła również systematycznie liczba kwerend prywatnych, które w latach 1931 i 1932 stanowiły ponad połowę ogólnej liczby przeprowadzonych przez archiwistów badañ ${ }^{36}$. Przeważały, zwłaszcza w drugiej połowie lat 30., kwerendy urzędowe. W Archiwum Państwowym w Poznaniu liczba kwerend wykonanych w latach 1920-1926 wynosiła 230, czyli średnio po kilkadziesiąt rocznie. Przeprowadzone $\mathrm{w}$ archiwum badania, oprócz wymiernych korzyści finansowych, które przyniosła przedstawiona wyżej kwerenda odszkodowawcza, miały także ogromne znaczenie dla urzędów państwowych i samorządowych $\mathrm{w}$ zakresie ustalenia nazw miejscowości, nazw jezior i rzek oraz herbów miejskich i wiejskich. Sporo kwerend archiwalnych wykonywało także Archiwum Państwowe w Wilnie. W latach 1920-1923 liczba ta wyniosła 478, a w latach następnych systematycznie wzrastała i wynosiła w 1924 roku 838, w 1925-1320, i w 1926-1645. Znakomitą większość z nich stanowiły kwerendy na rzecz Delegacji Polskiej w Mieszanej Komisji Specjalnej, związane z rewindykacją z Rosji zabytków kultury i sztuki, ale także na rzecz urzędów państwowych i samorządowych, instytucji społecznych, religijnych, oświatowych oraz dobroczynnych ${ }^{37}$.

Archiwiści międzywojenni prowadzili także szeroką działalność popularyzatorską, organizując wystawy historyczne, przyjmując $\mathrm{w}$ archiwach wycieczki uczniów i studentów oraz inne wizyty, kształtując przez to

${ }^{35}$ Kronika. Archiwum Wojskowe w Warszawie w latach 1919-1926, „Archeion” 1927, t. 2, s. 178; J. Stojanowski, Archiwum Akt Nowych w Warszawie, [w:] Straty, t. 2, Warszawa 1956, s. 236.

${ }^{36}$ Sprawozdanie z działalności archiwów państwowych. Rok 1928, red. W. Łopaciński, „Archeion” 1930, t. 6-7, s. 50; Sprawozdanie... Rok 1930, red. W. Łopaciński, "Archeion” 1931, t. 9, s. 77-78; Sprawozdanie... Rok 1931, oprac. W. Łopaciński, „Archeion” 1932, t. 10, s. 39; Sprawozdanie... Rok 1932, oprac. W. Łopaciński, „Archeion” 1933, t. 11, s. 39; Sprawozdanie... Lata 1933 i 1934, oprac. A. Rybarski, "Archeion” 1935, t. 13, s. 249-250; Sprawozdanie... Rok 1935, oprac, A. Rybarski, "Archeion" 1936, t. 14, s. 147; Sprawozdanie... Rok 1936, oprac. A. Rybarski, "Archeion” 19371938, t. 15, s. 188-189 (tabela); Sprawozdanie... Rok 1937, oprac. A. Rybarski, "Archeion” 19381939 , t. 16, s. $192-193$.

37 LCVA Wilno, Archiwum Państwowe w Wilnie. Ministerstwo Wyznań religijnych i Oświecenia Publicznego. Rzeczypospolita Polska 1920-1939, zespół nr 286, sygn. 9, s. 1-259; sygn. 48, s. 1-697; sygn. 82, s. 1-753; Kronika, red. W. Łopaciński, Archiwum Państwowe w Wilnie w latach 1919-1926, „Archeion” 1928, t. 4, s. 172. 
świadomość narodową i postawy patriotyczne w społeczeństwie polskim. Największym przedsięwzięciem państwowej służby archiwalnej $\mathrm{w}$ dwudziestoleciu międzywojennym w zakresie popularyzacji archiwów i udostępniania ich zasobów, tak w społeczeństwie polskim, jak i za granicą, była prezentacja ich dorobku oraz zasobów na Powszechnej Wystawie Krajowej w Poznaniu w 1929 roku. Celem wystawy zorganizowanej pod patronatem prezydenta Ignacego Mościckiego na dziesięciolecie niepodległości Polski była prezentacja osiągnięć odrodzonego państwa polskiego $\mathrm{w}$ wielu dziedzinach $^{38}$. Wystawa przygotowana przez archiwa miała przedstawić przede wszystkim znaczenie historyczne, naukowe i społeczne archiwów państwowych. Przygotowaniami objęto wszystkie archiwa państwowe. Archiwalia wypełniły też całkowicie salę historii szkolnictwa polskiego przygotowaną przez Ministerstwo Wyznań Religijnych i Oświecenia Publicznego, gdzie zaprezentowano m.in.: dokumentację dotyczącą Uniwersytetu Jagiellońskiego, Akademii Zamojskiej, Komisji Edukacji Narodowej oraz dzieje szkolnictwa polskiego w czasach niewoli. Dla pełnego obrazu dodać należy, że materiały archiwalne ilustrowały również wystawy Ministerstwa Spraw Zagranicznych i Ministerstwa Skarbu, przedstawiając dzieje polskich tradycji państwowotwórczych w zakresie dyplomacji i skarbowości ${ }^{39}$. Wystawa, która trwała od 16 maja do pierwszych dni października 1929 roku, poprzedzona była jednodniową prezentacją wszystkich eksponatów w salach Wydziału Archiwów Państwowych w Warszawie w niedzielę 21 kwietna 1929 r. Przyczyniła się ona w znaczącym stopniu do umocnienia znaczenia roli archiwów w świadomości społecznej, pokazała społeczeństwu polskiemu i gościom zagranicznym bogate tradycje narodu polskiego. Reprodukcje dokumentów archiwalnych prezentowane na tej wystawie były też wielokrotnie wypożyczane dla celów dydaktycznych w całym kraju.

Oprócz udziału w Powszechnej Wystawie Krajowej, w Poznaniu archiwa państwowe organizowały także pokazy archiwaliów we własnych gmachach, poza tym brały czynny udział w licznych mniejszych, tematycznych wystawach organizowanych w kraju lub za granicą. Wszystkie działania popularyzatorskie miały ogromny wpływ na kształtowanie świadomości narodowej i postaw patriotycznych w odrodzonym państwie polskim i w efekcie przyczyniły się także do wzrostu rangi oraz popularności archiwów jako urzędów państwowych. Dzięki ogromnemu wysiłkowi archiwistów w zakresie ewidencjonowania i opracowania zasobu archiwa, zwłaszcza te umiejscowione w ośrodkach uniwersyteckich, coraz lepiej spełniały swoje zadanie, jakim było służenie nauce historycznej i społeczeństwu. Bardzo liczne grono

${ }^{38}$ K. Konarski, S. Ptaszycki, Archiwa Państwowe na Powszechnej Wystawie Krajowej w Poznaniu, „Archeion" 1930, t. 6-7, s. 1.

${ }^{39}$ Tamże, s. 19-20. 
archiwistów tego okresu wniosło także znaczący wkład w rozwój badań naukowych, zarówno w zakresie historii, jak i archiwistyki. Wyniki tych badań służyły i nadal służą kolejnym pokoleniom archiwistów. Liczne grono archiwistów tego okresu miało znaczący wpływ na rozwój badań naukowych, zarówno $\mathrm{w}$ zakresie historii, jak i archiwistyki. W dorobku naukowym archiwistów międzywojennych znajdują się: liczne wydawnictwa źródłowe, prace z zakresu historii Polski i powszechnej oraz archiwistyki (podręczniki, broszury $)^{40}$. Do bezspornych osiągnięć w tym zakresie należy również utworzenie w 1927 r. własnego czasopisma archiwalnego "Archeion”, podejmującego najważniejsze problemy archiwistyki polskiej i światowej, które odegrało w przeszłości i odgrywa nadal ważną rolę w środowisku archiwistów polskich.

Przedstawione wyżej przykłady pokazują bardzo szeroki udział archiwistów międzywojennych w służbie państwa i społeczeństwa. Aktywność ta była wszechstronna i służyła nie tylko działalności państwa i jego organów, ale - co jest szczególnie ważne - w znaczący sposób kształtowała i umacniała świadomość narodową i patriotyczne postawy społeczeństwa polskiego. Warto o tym pamiętać $\mathrm{w}$ setną rocznicę odzyskania przez Polskę niepodległości i początków polskiej państwowej służby archiwalnej odrodzonej Rzeczypospolitej.

\section{Bibliografia}

\section{Materiały źródłowe}

Archiwum Państwowe Poznań, Archiwum Państwowe w Poznaniu, sygn. 6.

Lietuvos Centrinis Valstybés Archyvas, Vilnius, Archiwum Państwowe w Wilnie. Ministerstwo Wyznań Religijnych i Oświecenia Publicznego. Rzeczpospolita Polska, 1920-1939, zespół nr 286, sygn. 8.

„Dziennik Praw Państwa Polskiego” 1919, nr 14, poz. 182.

„Dziennik Ustaw” 1927, nr 115, poz. 980.

„Dziennik Ustaw” 1930, nr 80, poz. 629.

MSW, Okólnik nr 138, 6 VII 1929.

M. Motas, Pierwsze akty prawne o organizacji polskich archiwów państwowych i opiece nad archiwaliami z 31 lipca 1818 r. i z 7 lutego 1919 r., "Archeion” 1968, t. 50, s. 27-41.

R. Piechota, B. Jagiełło, M. Motas, Pierwsze protokoty Rady Archiwalnej, cz. I, Protokoty Rady Archiwalnej, cz. II, Regulaminy archiwalne, „Teki Archiwalne” 1971, t. 13, s. 103-193.

„Rocznik Polityczno-Gospodarczy” 1938.

Dział Urzędowy. Protokół posiedzeń VI-ej sesji Rady Archiwalnej w dn. 19 i 20 grudnia 1928 r., "Archeion" 1929, t. 5, s. 1-27.

${ }^{40}$ Na ten temat szeroko: K. Kaczmarczyk, Literatura archiwalna odrodzonej Polski (1918-1926), "Archeion" 1928, t. 3, s. 84-168; B. Ryszewski, O badaniach i dorobku archiwistyki polskiej z lat 1918-1939, „Acta Universitatis Nicolai Copernici” 1984, Historia - XIX, Nauki Humanistyczno-Społeczne, z. 47, s. 173-205; I. Mamczak-Gadkowska, Archiwa państwowe, s. 341-380. 
Dział urzędowy. Protokół posiedzeń VII-ej sesji Rady Archiwalnej w dn. 28 i 29 marca 1930 r., "Archeion" 1930, t. 8, s. 5-26.

Sprawozdanie z działalności archiwów państwowych. Rok 1928. Rok 1929, red. W. Łopaciński, „Archeion” 1930, t. 6-7, s. 11-153.

Sprawozdanie z działalności archiwów państwowych. Rok 1930, red. W. Łopaciński, „Archeion” 1931, t. 9, s. 30-115.

Sprawozdanie z działalności archiwów państwowych. Rok 1931, red. W. Łopaciński, "Archeion" 1931, t. 9, s. 1-115.

Sprawozdanie z działalności archiwów państwowych. Rok 1932, oprac. W. Łopaciński, „Archeion” 1933, t. 11, s. 97-147.

Sprawozdanie z działalności archiwów państwowych. Rok 1931, oprac. W. Łopaciński, „Archeion” 1932, t. 10, s. 1-64.

Sprawozdanie z działalności archiwów państwowych. Lata 1933 i 1934, oprac. A. Rybarski, „,Archeion” 1935, t. 13 , s. 187-266.

Sprawozdanie z działalności archiwów państwowych. Rok 1935, oprac. A. Rybarski, „Archeion” 1935, t. 14, s. 101-171.

Sprawozdanie z działalności archiwów państwowych. Rok 1936, oprac. A. Rybarski, „Archeion” 19371938 , t. 15, s. 154-202.

Sprawozdanie z działalności archiwów państwowych. Rok 1937, oprac. A. Rybarski, „Archeion” 1938-1939, t. 16, s. 155-217.

Sprawozdanie z dziatalności WAP w roku 1935, „Archeion” 1936, t. 14, s. 85-101.

Sprawozdanie z działalności WAP w roku 1936, „Archeion” 1937-1938, t. 15, s. 141-154.

Sprawozdanie a dziatalności WAP w roku 1937, „Archeion” 1938-1939, t. 16, s. 133-155.

\section{Opracowania}

Barwiński E., O archiwa miejskie i gminne (koreferat), [w:] Pamiętnik VI Powszechnego Zjazdu Historyków Polskich, t. I, Lwów 1935, s. 432-438.

Biernat C., Zatarg gdańsko-niemiecki w latach 1919-1930 o profil Archiwum Gdańskiego, "Archeion” 1968 , t. 48, s. 85-97.

Biernat C., Spór archiwalny polsko-gdańsko-niemiecki w okresie międzywojennym 1919-1939, Warszawa 1969.

Dragan M., Polsko-gdańsko-niemiecki spór archiwalny w okresie międzywojennym (1919-1939), „Archeion" 1963, t. 39, s. 165-203.

Kaczmarczyk K., Archiwum Państwowe w Poznaniu w latach 1919-1926, „Archeion” 1928, t. 4, s. $145-146$

Kaczmarczyk K., Literatura archiwalna odrodzonej Polski (1918-1926), „Archeion” 1928, t. 3, s. 84168.

Karwasińska J., La remise des archives dans les traites de l'Est Europeen, [w:] VIII-e Congres International des Sciences Historiques, V. I - Communication presentees, Zurich 1938.

Archiwum Akt Dawnych m. Łodzi w r. 1926, "Archeion” 1928, t. 2, s. 178-182.

Archiwum Akt Dawnych m. Pabianic, "Archeion” 1928, t. 2, s. 182-184.

Kieniewicz S., Archiwum Skarbowe w Warszawie, [w:] Straty bibliotek i archiwów warszawskich w zakresie rękopiśmiennych źródeł historycznych, t. 2, Archiwa porozbiorowe i najnowsze, Warszawa 1956, s. 17-71.

Konarski K., Dziesięciolecie kursów archiwalnych, „Archeion” 1935, t. 13, s. 183-187.

Konarski K., Ptaszycki S., Archiwa Państwowe na Powszechnej Wystawie Krajowej w Poznaniu, "Archeion" 1930, t. 6-7, s. 1-22.

Kronika. Archiwum Oświecenia Publicznego w Warszawie w latach 1915-1926, „Archeion” 1928, t. 2, s. 166-177.

Kronika. Archiwum Wojskowe w Warszawie w latach 1919-1926, „Archeion” 1927, t. 4, s. 173-178. 
Kronika. Archiwum Państwowe w Wilnie w latach 1919-1926, „Archeion” 1928, t. 4, s. 161-173.

Kronika. Archiwum Główne w Warszawie. Lata 1915-1926, "Archeion” 1928, t. 4, s. 130-147.

Librowski S., Stan i potrzeby archiwów kościelnych oraz program pracy na najbliższy okres, „Archiwa, Biblioteki i Muzea Kościelne" 1959, t. 1, z. 1, s. 20-33.

Librowski S., Dotychczasowe osiagnięcia w dziedzinie reformy organizacji archiwów kościelnych $w$ Polsce, "Archiwa, Biblioteki i Muzea Kościelne” 1961, t. 3, z. 1-2, s. 3-24.

Mamczak-Gadkowska I., Józef Paczkowski i jego wkład w budowę polskiej służby archiwalnej, Warszawa-Łódź 1990.

Mamczak-Gadkowska I., Archiwa państwowe w II Rzeczypospolitej, Poznań 2006.

Paczkowski J., La remise des actes en connexion les changements de frontieres les Etatas, [w:] La Pologne au V-e Congres International des Sciences Historiques Bruxelles 1923, Warszawa 1924, s. 199_ 211.

Radtke I., Dzieje Archiwum Państwowego w Poznaniu (1869-1999), „Poznański Rocznik Archiwalno-Historyczny" 1999/2000, r. VI/VII, s. 31-32.

Robótka H., Archiwa państwowe i reforma biurowości w Polsce międzywojennej, "Archeion" 1994, t. 93, s. 83-97.

Robótka H., Kancelaria urzędów administracji państwowej II Rzeczypospolitej. (Procesy aktotwórcze), Toruń 1993.

Ryszewski B., O badaniach i dorobku archiwistyki polskiej z lat 1918-1939, „Acta Universitatis Nicolai Copernici" 1984, Historia - XIX, Nauki Humanistyczno-Społeczne, z. 47, s. 173-205.

Siemieński J., Respect des Fonds. Application international, [w:] VIII-e Congres International des Sciences Historiques, V. I - Communication presentees, Zurich 1938.

Stojanowski J., Archiwum Akt Nowych w Warszawie, [w:] Straty bibliotek $i$ archiwów warszawskich w zakresie rękopiśmiennych źródeł historycznych, t. 2, Archiwa porozbiorowe i najnowsze, Warszawa 1956, s. 235-357.

Irena Mamczak-Gadkowska

\section{Archiwiści II Rzeczypospolitej w służbie państwa i społeczeństwa}

\section{Streszczenie}

Archiwiści okresu międzywojennego odegrali znaczącą rolę państwowotwórczą w procesie odbudowy polskiej państwowości. Swoją działalność na rzecz odradzającego się państwa rozpoczęli już w trakcie I wojny światowej, zapobiegając niszczeniu i wywożeniu archiwaliów za granicę i przygotowując pierwsze projekty regulacji normatywnych $\mathrm{w}$ odniesieniu do archiwów i służby archiwalnej. Po odzyskaniu niepodległości koncentrowali swój wysiłek na budowaniu scentralizowanej i sprawnie działającej sieci archiwalnej, zarówno w zakresie działań legislacyjnych, jak i organizatorskich, oraz na działaniach rewindykacyjnych. Prowadzili także szeroką działalność popularyzatorską, kształtując przez to świadomość narodową i postawy patriotyczne. Wielu archiwistów z tego okresu wniosło także znaczący wkład w rozwój badań naukowych, zarówno w zakresie historii, jak i archiwistyki.

Słowa kluczowe: archiwa, archiwiści, funkcje archiwów, legislacja, rewindykacja, popularyzacja, państwo, społeczeństwo, ochrona dziedzictwa narodowego, świadomość narodowa 
Irena Mamczak-Gadkowska

\title{
Archivists in the Second Polish Republic at the service of the state and society
}

\begin{abstract}
In the period of 1918-1939, archivists played an important role in the process of reconstructing the Polish statehood. They began their work for the rebirth of Poland as early as during the First World War, by preventing the destruction of archival materials and taking them abroad, and preparing the first drafts of normative regulations regarding archives and archival service. After Poland had regained independence, they focused on building a centralized and efficient network of archives. This involved work on legislation and organizational matters, as well as repossession actions. They also actively popularized the subject, thus shaping national awareness and patriotic attitudes. Many archivists from this period significantly contributed to the development of scientific research, both in the field of history and in archival studies.
\end{abstract}

Keywords: archives, archivists, function of archives, legislation, repossession, popularization, state, society, national heritage protection, national awareness 